\title{
OBITUARY
}

\author{
DR. C. E. P. BROOKS, I.S.O.-I888-1957
}

Charles Ernest Pelham Brooks, who died at Ferring, Sussex on 14 December 1957, at the comparatively early age of 69 , was a great and distinguished climatologist, giving special attention to the study of climatic changes on the historical and geological time scales. His professional life of many-sided activities was identified with the Meteorological Office, but to members of the British Glaciological Society he will be best remembered for his researches on ice sheets and the theory of Ice Ages.

In his monumental work, Climate through the Ages, Brooks shows by powerful reasoning, reinforced with considerable mathematical skill, that glacial epochs can be brought about solely by geographical factors. This seems in open conflict with Sir George Simpson's solar radiation theory of Ice Ages, which was revived with masterly logic in the issue of the Quarterly Fournal of the Royal Meteorological Society for October 1957 and is to be extended later on a more quantitative basis. It may well be, however, that when the two points of view can be properly co-ordinated a measure of reconciliation between them will be found. Certainly this important issue will be watched with interest as the years go on.

Brooks' last book, The English Climate, a most informative and pleasantly written volume, appeared as recently as 1954. Soon afterwards, however, his health began to fail and it seems likely that the immense output of work which he accomplished through many years had worn him out somewhat prematurely.

L. C. W. Bonacina

\section{Dr. B. M. CWILONG}

WE also record the comparatively early death of Dr. B. M. Cwilong in London in the beginning of this year. Dr. Cwilong was born in Russia of Polish parents. As a young man he went to the Clarendon Laboratory at Oxford. There, under Professor G. M. B. Dobson, he carried out important general research work on atmospheric ice crystals, while specializing in the physics of condensation nuclei.

Dr. Cwilong was interested in many other aspects of ice and the writer of this note remembers with gratitude the many interesting discussions with him at the Clarendon Laboratory and much helpful advice.

G. Seligman

\section{PROFESSOR (EMERITUS) FRITZ MACHATSCHEK-1876-1957}

WHEN Fritz Machatschek died on 9 September 1957 the world lost a distinguished glaciologist. Born in Wischau of the old Empire, in 1876, he obtained his doctor's degree at Vienna under Penck, his thesis being based on climatological investigations on the glaciers of the Sonnblick group in the Central Alps. In 1905 he qualified for residence in Vienna as a university lecturer, with his thesis on the morphology of the Jurassic in the Swiss Jura.

In 1915 he became Professor of Geography in Prague; in 1924 he moved to Zürich and in 1925 he went back to Vienna. In 1935 he finally took up residence in Munich. Thus his activities were spread over many of the classic seats of glaciological research. His particular interest was in geomorphology and in this way he came into close touch with glaciology itself. His small, comprehensive book Gletscherkunde, which was published in Leipzig in 1902 as part of the Göschen Collection and reprinted in 1917, was wholly excellent. In it he covered the glaciers from the points of view of both geographers and geologists in an unusually clear and easily understood manner. 